\title{
Effect of uncoupling treatments on FSH-induced hyperpolarization of immature rat Sertoli cells from Sertoli cell-enriched cultures*
}

\author{
A. Roche and M. Joffre \\ Laboratoire de Physiologie Animale, CNRS: UA 290 "Biomembranes", Faculté des Sciences, \\ Université de Poitiers, F 86022 Poitiers Cedex, France
}

\begin{abstract}
Summary. Sertoli cell-enriched cultures isolated from immature rat testes by enzymic treatments were investigated by intracellular microelectrode recordings. The hyperpolarization of cells induced by FSH was independent of the age of the rats (7-37 days) and was unchanged by exposure to a hormone-free medium or to a glycine buffer of pH 3. It was reduced by treatments which decreased the electrical coupling between cells either by an increase of intracellular calcium [i.e. calcium ionophore (A 23187, $5 \times 10^{-6} \mathrm{M}$ ), general anaesthetic (heptanol, $3.5 \mathrm{mM}$ ) and uncoupler of oxidative phosphorylations (carbonylcyanide m-chlorophenylhydrazone-CCmP, $10^{-6} \mathrm{M}$ )] or by a decrease of extracellular calcium [i.e. 0Ca + EGTA (1 mM) medium]. These effects were partly or totally reversed by a recovery period in a drug-free medium. Similar results were obtained by an exposure to trypsin $(0.05 \%)$ followed by a second mechanical dispersion, but new cell hyperpolarization was induced by a new exposure to FSH. This electrophysiological study suggests an initial effect of FSH on the junctional complex between Sertoli cells, then the control by calcium of this complex.
\end{abstract}

Keywords: Sertoli cells; FSH; electrophysiology; A 23187; heptanol; membrane permeability; calcium; rat

\section{Introduction}

The Sertoli cells of the testes are involved in spermatogenesis. These cells provide a nutritional and mechanical support for the germ cells (Saez et al., 1985). They are exocrine cells which secrete a $\mathrm{K}^{+}$-enriched fluid into the lumen of seminiferous tubules (see review: Waites \& Gladwell, 1982).

Follicle-stimulating hormone (FSH) elicits a number of morphological and biochemical events in the Sertoli cells of immature testes. An electrophysiological study performed on cultured Sertoli cells showed that FSH induces the hyperpolarization of the cell (Joffre \& Roche, 1988) and the results suggested that FSH, by means of cAMP-dependent mechanisms, simultaneously increases $\mathrm{Na} / \mathrm{K}$ pump activity and promotes $\mathrm{Na} / \mathrm{Ca}$ influx through an ionic process, blocked by cobalt. This, in turn, regulates the intracellular concentration and the exit of $\mathrm{K}^{+}$from the cell through a $\mathrm{K}^{+}$ channel, blocked by quinidine. Such an electrophysiological study corresponds closely with the radioisotopic and chemical results obtained in the whole seminiferous tubules concerning the exocrine function of Sertoli cells (see review: Waites \& Gladwell, 1982).

Tight and gap junctions occur between Sertoli cells in the mature rat testis (Dym \& Fawcett, 1970). Their formation is a prerequisite for the onset of fluid secretion (Waites \& Gladwell, 1982) which starts between 15 and 19 days of age in the rat (Vitale et al., 1973). This junctional complex remains unchanged even after hypophysectomy (Setchell, 1970; Johnson, 1970; Gilula et al., 1976;

*Reprint requests to Dr M. Joffre. 
Hagenas et al., 1978). These junctional complexes also occur on monolayer cultures of Sertoli cells, isolated from rat testes and cultured in medium containing FSH (Solari \& Fritz, 1978; Hadley et al., 1985).

Studies of electrical coupling between cells have been performed on several exocrine glands (i.e. exocrine pancreas, salivary and lacrimal glands). They showed that messengers (such as hormones and drugs) which affect the functional state of the gap junctions linking neighbouring cells modify the recordings obtained by the microelectrode technique (Iwatsuki \& Petersen, 1978a, b; Petersen, 1980; Ginsborg \& House, 1980; Loewenstein, 1981; Poisner \& Trifaro, 1985).

We have measured the membrane potential on Sertoli cells isolated from testes of immature rats, exposed to FSH before different uncoupling treatments. We have also studied the agedependence of FSH and the effects of FSH deprivation. Preliminary accounts of this work have been published in abstract form (Roche \& Joffre, 1985, 1986).

\section{Materials and Methods}

Preparation of enriched Sertoli cells and culture. The Sertoli cells were isolated from the testes of 7-37-day-old rats (Wistar). Two procedures were successively used for the isolation and culture of the cells: Procedure 1, modified from that of Welsh \& Wiebe (1975), and Procedure 2, modified from that of Verhoeven et al. (1979). Both procedures have been described in detail (Joffre \& Roche, 1988). For both procedures the cells were treated with collagenase (Boehringer Mannheim France, Meylan, France) and pancreatin (Grade VI: Sigma, St Louis, MO, USA).

For Procedure 1, the suspensions containing the tubule fragments were dispersed by being slowly passed 5-10 times (depending upon the age of the rats) through a syringe needle (17 gauge). The Sertoli cells were separated from the other cells by centrifugation through a gradient of Percoll (Pharmacia France; Les Ulis, France) by the procedure used for Leydig cells (Joffre et al., 1984).

For Procedure 2, the mass of reaggregated tissues, containing peritubular cells and tubule fragments, were washed 5 times by gently shaking by hand to remove the isolated tubular fragments. Then, the washed tubules were dispersed according to Procedure 1 .

The washed cells were resuspended in MEM medium (Eurobio, MEM 2116, Paris, France) (Procedure 1) or RPMI (Flow Laboratories SA Asnières, France) (Procedure 2). They were cultured in $35 \mathrm{~mm}$ plastic Petri dishes (Falcon 3001 or Nunclon), according to Steinberger et al. (1975) (Procedure 1) or Verhoeven et al. (1979) (Procedure 2).

Culture media. Two culture media were used.

For Procedure 1, Medium MEM (Eurobio) was supplemented by L-glutamine ( $2 \mathrm{~mm}$; Sigma), sodium pyruvate ( $1 \mathrm{~mm}$; Sigma), sodium bicarbonate (20 mM; Eurobio Grand Island, NY, USA), and fetal calf serum ( $10 \%$; Gibco Laboratories Inc, Grand Island, NY, USA).

For Procedure 2, RPMI 1640 medium (Flow Laboratories) (including $20 \mathrm{~mm}$-Hepes) was supplemented by Lglutamine ( $4.8 \mathrm{~mm}$; Flow Laboratories) and sodium bicarbonate ( $20 \mathrm{~mm}$; Eurobio).

Streptomycin sulphate $(100 \mu \mathrm{g} / \mathrm{ml}$; Gibco) and penicillin $\mathrm{G}$ (100 i.u./ml; Gibco) were added to both media. Culture media were changed at 2 -day intervals. All culture dishes were incubated at $34^{\circ} \mathrm{C}$, in a humidified incubator, in an atmosphere of $5 \% \mathrm{CO}_{2}$.

Intracellular recordings. Intracellular recordings of the membrane potential were performed by the technique of Joffre $e$ al. (1984). The membrane potentials were recorded between the intracellular microelectrode fixed in a nacelle filled with $3 \mathrm{M} \mathrm{KCl}$ and an $\mathrm{Ag} / \mathrm{AgCl}$ reference electrode (World Precision Instruments New Haven, CT, USA). The glass capillary microelectrodes (tip diameter $0 \cdot 1-0.2 \mu \mathrm{m}$ ) were filled with $2 \mathrm{M}$-potassium citrate $(\mathrm{pH} 7 \cdot 2$ ) and had a resistance ranging between 50 and $100 \mathrm{M} \Omega$.

Potentials were recorded with a WPI 707 microprobe System (World Precision Instruments) directly on the screen of an oscilloscope (Tektronix 5115, Beaverton, OR, USA).

The standard bathing solution used during the recordings was Earle's solution containing (mM): $\mathrm{Na}^{+} 121 \cdot 7 ; \mathrm{K}^{+}$ $5 \cdot 4 ; \mathrm{Ca}^{2+} 1 \cdot 8 ; \mathrm{Mg}^{2+} 0 \cdot 8 ; \mathrm{Cl}^{-} 125 \cdot 3 ; \mathrm{PO}_{4} \mathrm{H}_{2}{ }^{-} 0 \cdot 9 ; \mathrm{SO}_{4}{ }^{2-} 0 \cdot 8 ;$ glucose $1 \mathrm{I}$ and Hepes 5 .

This solution was adjusted so that $\mathrm{pH}$ was $7 \cdot 4$, osmolarity was $290-300 \mathrm{mosmol}$ and temperature was $34 \pm 1{ }^{\circ} \mathrm{C}$.

Experimental procedures. The recordings were performed from Day 3 of culture onwards. FSH or uncoupling drugs were dissolved in the culture medium, during the incubation, or in the Earle's solution, during the electrical measurements.

All values are expressed either as individual values or as means \pm s.e.m. The statistical significance of the difference between the means was established using Student's $t$ test.

Hormone and drugs. Ovine FSH (NIADDK-oFSH-S $\mathrm{S}_{15}$ and $-\mathrm{S}_{16}$ ) was provided by the NIAMDD Pituitary Hormone Distribution Program. Calcium ionophore (A 23187) (Boehringer-Mannheim) (stock solutions in methanol: $2 \times 10^{-3} \mathrm{M}$ ), carbonylcyanide m-chlorophenyl hydrazone (CCmP) (Sigma) heptanol (Merck, Darmstadt, FRG), 
ouabain (Nativelle, Paris, France) and trypsin (Sigma) were dissolved in the culture medium during the incubation or in the Earle's solution during the electrophysiological measurements.

\section{Results}

\section{Morphology of the Sertoli cell-enriched cultures}

Two types of Sertoli cell-enriched cultures were used to explore the electrophysiology of Sertoli cells and the FSH stimulation. In both, the cell aggregates attached themselves to the plastic dishes and flattened out. In Procedure 1 they were surrounded by peritubular myoid cells, leading to the formation of nodules. Such myoid cells were prevented by the Procedure 2 in which the Sertoli cells formed a cell monolayer, having the morphological features of a thin epithelium, as previously described (Dorrington et al., 1975; Steinberger et al., 1975; Solari \& Fritz, 1978; Hadley et al., 1985; Roche, 1986; Joffre \& Roche, 1988). Some germ cells were still present in both culture types. They adhered to the apical surface of the monolayer (Hadley et al., 1985; Joffre \& Roche, 1988) and were largely eliminated by changing the culture medium. The remaining germ cells and the Leydig cells were always discarded from the experiments, when the Sertoli cells were impaled with the microelectrode, under phase-contrast microscopic control. Thus, only Sertoli cells were tested throughout this experiment.

\section{Irreversibility of the effect}

The membrane potential of FSH-stimulated cells did not return to the control values when the stimulus was removed by incubating the cells in a hormone-free medium for periods of $24-72 \mathrm{~h}$ (Fig. 1).

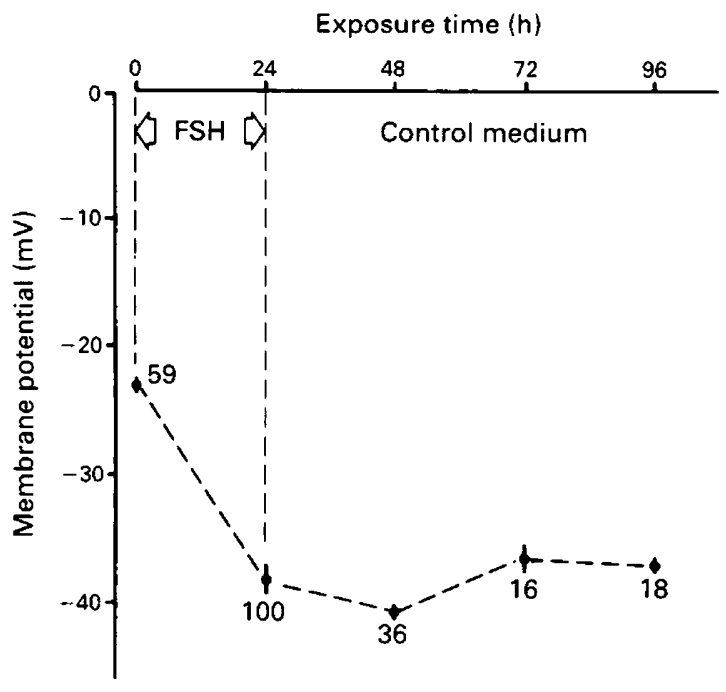

Fig. 1. Recovery period of FSH-induced hyperpolarization after a $24-\mathrm{h}$ exposure to $2.9 \mu \mathrm{g}$ oFSH-S16/ml. The cells were isolated from 17-day-old rats by Procedure 2 (see 'Materials and Methods') and cultured for 3-7 days before treatment. Each point represents the mean potential \pm s.e.m. for the no. of impaled cells indicated. Values were obtained from 3 different cultures. The control medium without FSH was changed every day. 
Similar results were obtained when a low-pH glycine buffer $(50 \mathrm{~mm}$-glycine, $150 \mathrm{~mm}-\mathrm{NaCl}$; $\mathrm{pH} 3 ; 4^{\circ} \mathrm{C}$ ) was added for 4 min to the Petri dishes, to remove the remaining membrane-bound FSH (Bernier \& Saez, 1985) $(-37 \cdot 0 \pm 0 \cdot 6 ; n=51, P>0 \cdot 05)$.

When maximal FSH stimulation was followed by another $24 \mathrm{~h}$ exposure to the hormone, the membrane potential did not become higher $(-35.5 \pm 1.3 \mathrm{mV} ; n=13, P>0.05)$.

\section{Influence of the age of rats on the FSH induced hyperpolarization}

The responsiveness of Sertoli cells to FSH decreases during the prepubertal maturation of rats (Steinberger et al., 1978; Means et al., 1980; Rich et al., 1983). Since, in vivo, the effect of FSH is age-dependent, the magnitude of the membrane potential of unstimulated Sertoli cells and the FSH-induced hyperpolarization were examined in Sertoli cell-enriched cultures from the testes of 7-37-day-old rats (i.e. before, during and after the blood-testis barrier is established). Whatever the age of the rats, the membrane potential of unstimulated Sertoli cells and the FSH-induced hyperpolarization did not significantly change (Fig. 2).

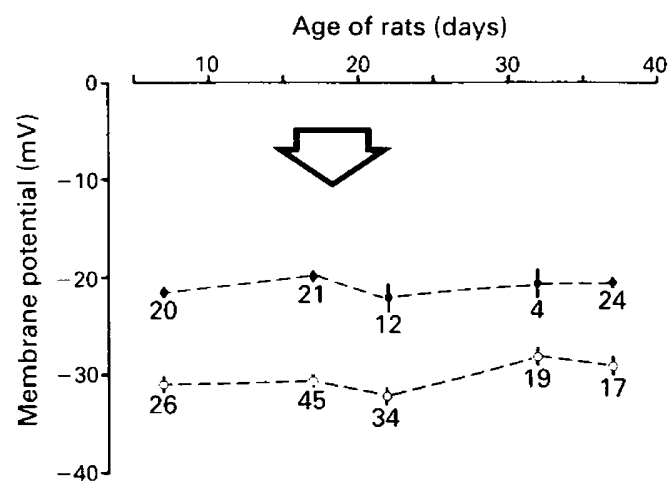

Fig. 2. The effect of age of the rats on the membrane potential of unstimulated cells $(0)$ and cells previously incubated for $24 \mathrm{~h}$ with FSH $(2.9 \mu \mathrm{g}$ oFSH-S16/ml) $(O)$. The cells were isolated by Procedure 1 (see 'Materials and Methods') and cultured for 3 days before treatment. Each point represents the mean potential \pm s.e.m. for the number of impaled cells indicated. Values were obtained from 3 different cultures. $\square$, Period when the blood-testis barrier is being established (Vitale et al., 1973).

\section{Effects of uncoupling treatments}

In several tissues, the intracellular calcium concentration is known to control the junctional permeability between neighbouring cells. A reduction in intracellular coupling can be caused by increasing the intracellular calcium to relatively high levels or by reducing the extracellular calcium concentration with EGTA (Loewenstein et al., 1967; Délèze, 1970; De Mello, 1975; Rose \& Loewenstein, 1975, 1976; Spray \& Bennett, 1985). To assess whether the junctional communications between Sertoli cells may modulate the FSH-induced hyperpolarization, monolayer cultures were exposed to different treatments which are known to reduce or abolish the electrical coupling between the cells.

\section{Increased intracellular calcium concentration}

The calcium ionophore A $23187(5 \mu \mathrm{M})$ rapidly decreased the membrane potential of unstimulated cells (Fig. 3a) and entirely suppressed the FSH-induced membrane hyperpolarization (Fig. 
3b). In the steady state, the mean values of membrane potential of unstimulated and FSHstimulated cells were not significantly different (Table 1). The ionophore effect of FSH-stimulated cells was partly reversed by a 30 -min period in the control medium.

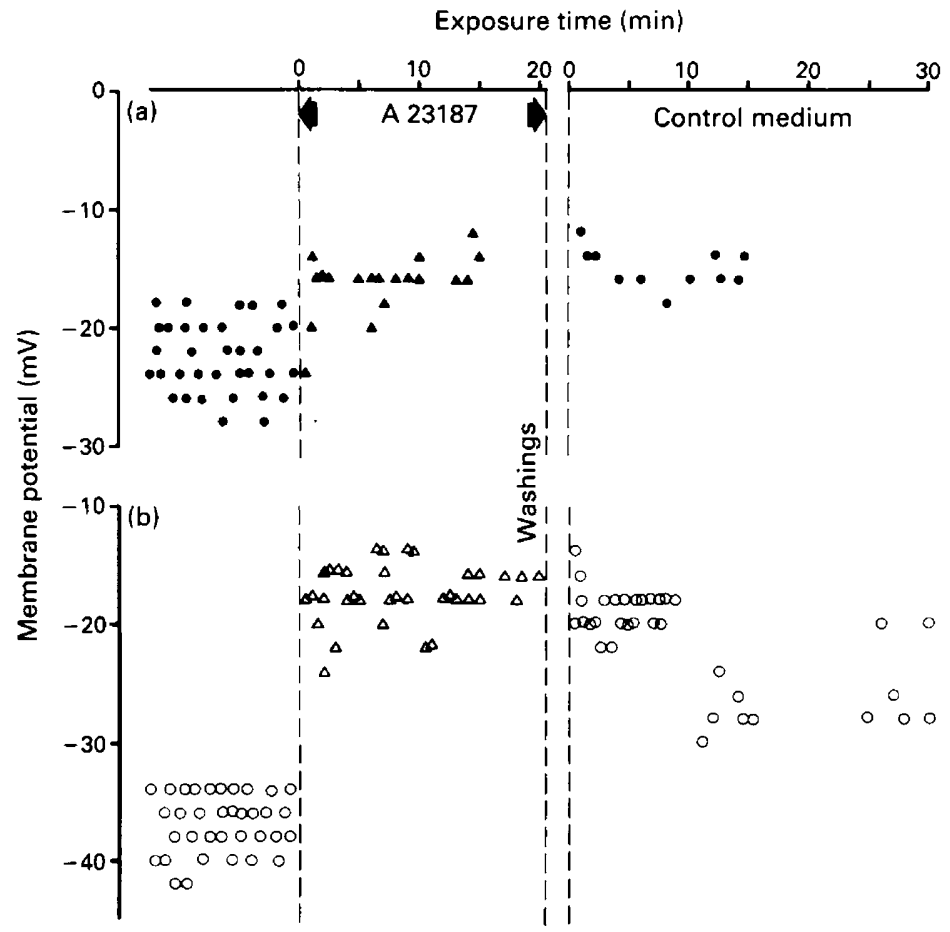

Fig. 3. Early effects of $A 23187\left(5 \times 10^{-6} \mathrm{M}\right)$ on the membrane potential of (a) unstimulated and (b) FSH-stimulated Sertoli cells. The cells were isolated from 17-day-old rats by Procedure 2 and cultured for 3-7 days before treatment. A 23187 (in stock solution in methanol $2 \times 10^{-3} \mathrm{M}$ ) was dissolved in the electrophysiological medium. After the measurement of potential in the control electrophysiological medium $(\Theta, O)$, A 23187 was added and membrane potentials were recorded at different times of exposure $(\Delta, \Delta)$. After $20 \mathrm{~min}$, A 23187 was washed out and replaced by the control medium. Each point represents the membrane potential of one impaled cell. Data were obtained from 3 cultures.

Table 1. Membrane potentials (mV) of immature rat Sertoli cells in monolayer culture recorded during various experimental procedures

\begin{tabular}{|c|c|c|c|c|}
\hline \multirow[b]{2}{*}{ Treatment } & \multicolumn{2}{|c|}{ Unstimulated cells } & \multicolumn{2}{|c|}{ FSH-stimulated cells } \\
\hline & Control & Treatment & Control & Treatment \\
\hline A $23187(5 \mu \mathrm{M})$ & $-22.7 \pm 0.5(33)$ & $-16 \cdot 4 \pm 0.6^{*}(19)$ & $-36 \cdot 6 \pm 0.4$ & $-17 \cdot 5 \pm 0.4^{*}(35)$ \\
\hline Heptanol (3.5 mM) & $-23 \cdot 0 \pm 0.5(18)$ & $-6 \cdot 5 \pm 0.4^{*}(12)$ & $-39 \cdot 7 \pm 0.4^{*}(38)$ & $-6 \cdot 4 \pm 0 \cdot 3^{*}(16)$ \\
\hline $\mathrm{CCmP}(1 \mu \mathrm{M})$ & $-21.5 \pm 0.3(13)$ & $-20.4 \pm 0.6$ & $-36 \cdot 6 \pm 0.6$ & $-22.8 \pm 0.6^{*}(31)$ \\
\hline $0 \mathrm{Ca}^{2+}+$ EGTA $(1 \mathrm{~mm})$ & $-21 \cdot 4 \pm 0.3(29)$ & $-20 \cdot 0 \pm 0 \cdot 3^{*}(26)$ & $-37 \cdot 7 \pm 0.3$ & $-24 \cdot 5 \pm 0 \cdot 3^{*}(52)$ \\
\hline
\end{tabular}

Values are means \pm s.e.m. of values determined in the steady state, for the no. of cells indicated in parentheses after a 24-h exposure to $2.9 \mu \mathrm{g}$ oFSH-S16 (NIADDK).

${ }^{*} P<0.01$ compared with control value. 
Heptanol (the heptyl alcohol or $n$-heptan-1-ol) is a general anaesthetic which suppresses electrical coupling in several structures (Johnston et al., 1980; Délèze \& Hervé, 1983; Bernardini et al., 1984) by an increase of intracellular calcium and an alkalinization of cytosol (Vassort et al., 1986). Applied to Sertoli cells, heptanol $(3.5 \mathrm{~mm})$ rapidly induced the depolarization of unstimulated and FSH-stimulated cells (Fig. 4a,b). In the two groups, a similar low membrane potential was recorded $(P>0 \cdot 05$; Table 1$)$. The effects of heptanol were entirely reversible (Fig. 4) but the kinetics of the recovery period varied. With unstimulated cells, the membrane potential rapidly returned to the control value $(-22.5 \pm 0.5 \mathrm{mV} ; n=24 ; P>0.05)$. For the FSH-stimulated cells, the membrane potential rapidly reached the same level $(-22.5 \pm 0.6 \mathrm{mV} ; n=21 ; P>0.05)$ then slowly rose to the control values for the stimulated cells (Fig. 4; Table 1).

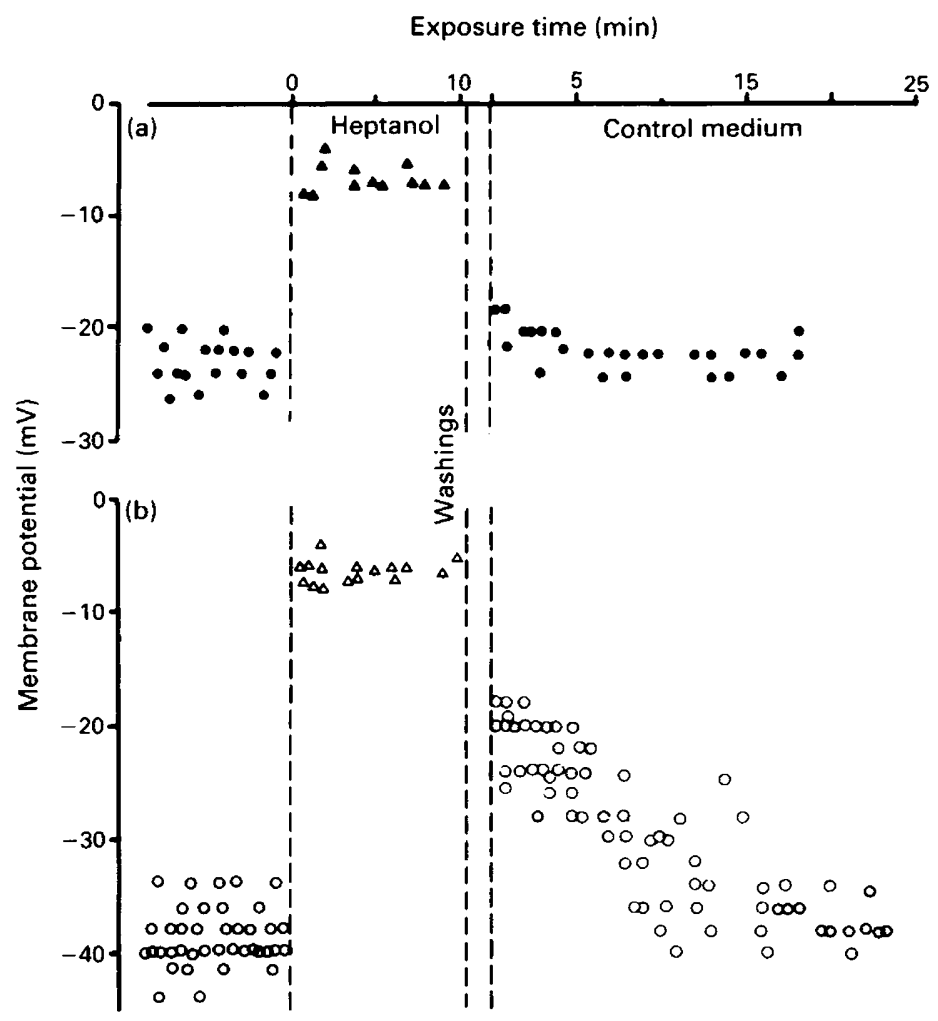

Fig. 4. Early effects of heptanol ( $3.5 \mathrm{~mm})$ on the membrane potential of (a) unstimulated and (b) FSH-stimulated Sertoli cells. The cells were isolated from 17-day-old rats by Procedure 2 and cultured for 3-7 days before treatment. Heptanol was dissolved in the electrophysiological medium. After the measurement of potential in the control electrophysiological medium ( $)$, $O)$, heptanol was added and membrane potentials were recorded at different times of exposure $(\boldsymbol{\Lambda}, \triangle)$. After $10 \mathrm{~min}$, heptanol was washed out and replaced by the control medium. Each point represents the membrane potential of one impaled cell. Data were obtained from 3 cultures.

The uncouplers of oxidative phosphorylations reduce the cell-to-cell conductance (Loewenstein, 1981). This reduction is related to a decrease of the intracellular ATP and to a simultaneous increase in the intracellular calcium levels (Politoff et al., 1969; Rose \& Rick, 1978; Délèze \& Hervé, 1983). Such a drug, carbonyl-cyanid-m-chlorophenyl-hydrazone (CCmP) was used to raise the intracellular $\mathrm{Ca}^{2+}$ concentration in neurones and in pancreatic $\beta$ cells (Plant et al., 1983; Rosario 
et al., 1985). An exposure to CCmP (1 $\mu \mathrm{M})$ did not significantly decrease the membrane potential of unstimulated cells (Fig. 5a; Table 1), but did abolish the FSH-induced hyperpolarization (Fig. 5b; Table 1). This effect was partly reversed by a $15-\mathrm{min}$ period in the control medium.

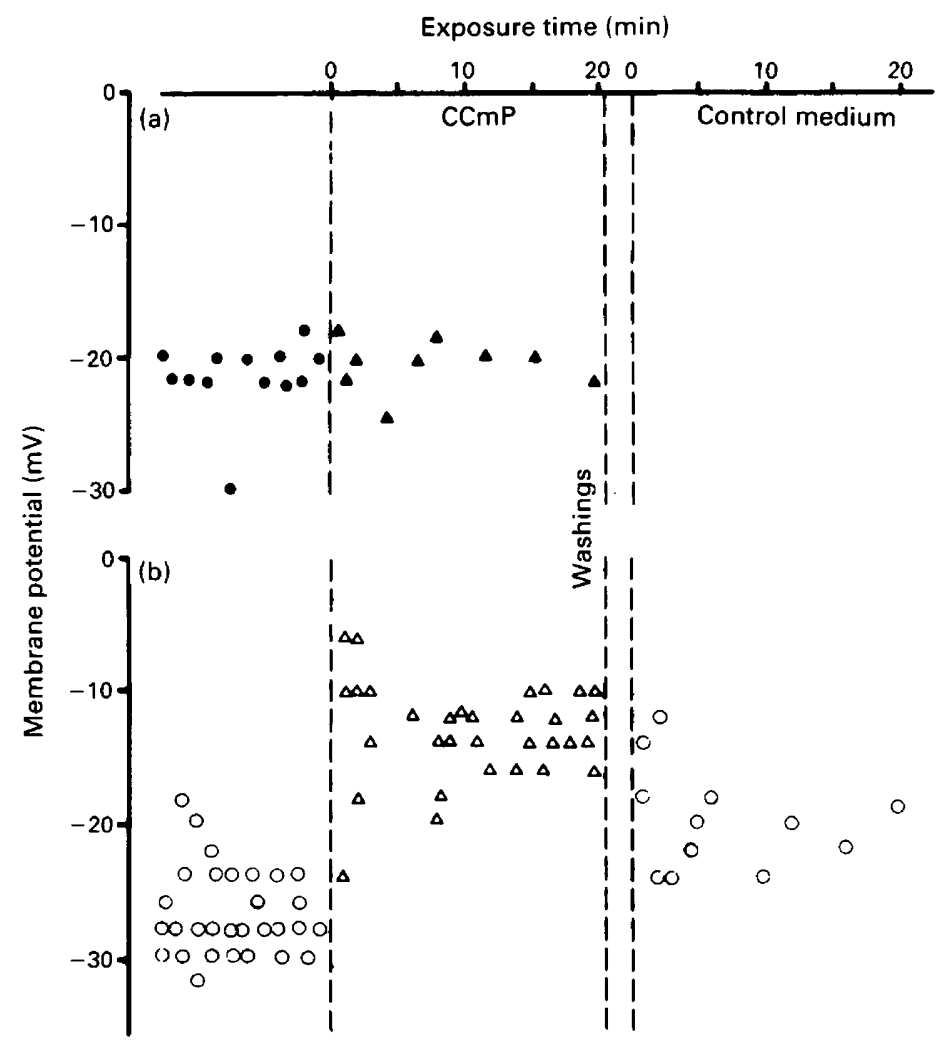

Fig. 5. Early effects of $\mathrm{CCmP}\left(10^{-6} \mathrm{M}\right)$ on the membrane potential of (a) unstimulated and (b) FSH-stimulated Sertoli cells. The cells were isolated from 17-day-old rats by Procedure 2 and cultured for 3-7 days before treatment. CCmP was dissolved in electrophysiological medium. After the measurement of potential in the control electrophysiological medium $(\mathbf{O}, \bigcirc), \mathrm{CCmP}$ was added and membrane potentials were recorded at different times of exposure $(\boldsymbol{\Delta}, \Delta)$. After $20 \mathrm{~min}, \mathrm{CCmP}$ was washed out and replaced by the control medium. Each point represents the membrane potential of one impaled cell. Data were obtained from 3 cultures.

\section{Decreased extracellular calcium concentration}

Exposure to 0 calcium medium did not change the membrane potential of unstimulated cells but slightly decreased from $-36.4 \pm 0.6 \mathrm{mV}(n=102)$ to $-32.4 \pm 0.6 \mathrm{mV}(n=128)(P<0.01)$ the FSH-induced hyperpolarization (Joffre \& Roche, 1988). A decrease of electrical coupling is observed when Chironomus salivary gland cells are exposed to 0 calcium solutions containing EGTA (Loewenstein et al., 1967). Figure 6 shows that an exposure to $0 \mathrm{Ca}+$ EGTA (1 mM) medium (giving about $10^{-9} \mathrm{M}$ calcium) slightly but significantly decreased the membrane potential of unstimulated cells (Table 1) and induced greater depolarization of FSH-stimulated cells $(P<0.01)$.

At the steady state, the membrane potential was higher in the FSH-stimulated than in the unstimulated cells $(P<0.01)$. As soon as the low calcium-EGTA medium was washed out the membrane potential returned to control values. 


\section{Effects of ouabain applied to cells}

Ouabain $\left(10^{-4} \mathrm{M}\right)$ does not affect the membrane potential of unstimulated cells, but decreases the membrane potential of FSH-stimulated cells $(P<0.01$; Joffre $\&$ Roche, 1988). When ouabain $\left(10^{-4} \mathrm{M}\right)$ was applied to unstimulated or FSH-stimulated cells previously depolarized by an uncoupling treatment (e.g. $0 \mathrm{Ca}+$ EGTA), this exposure did not move the membrane potential towards lower values (Fig. 6).

\section{Effects of trypsin treatment and mechanical dispersion}

The exposure of Chironomus salivary glands to a medium containing trypsin $(0.05 \%)$ leads to a rapid and irreversible uncoupling of cells (Loewenstein et al., 1967). A similar experimental procedure could not be used in this study, since the early effect of trypsin induced the loosening of the

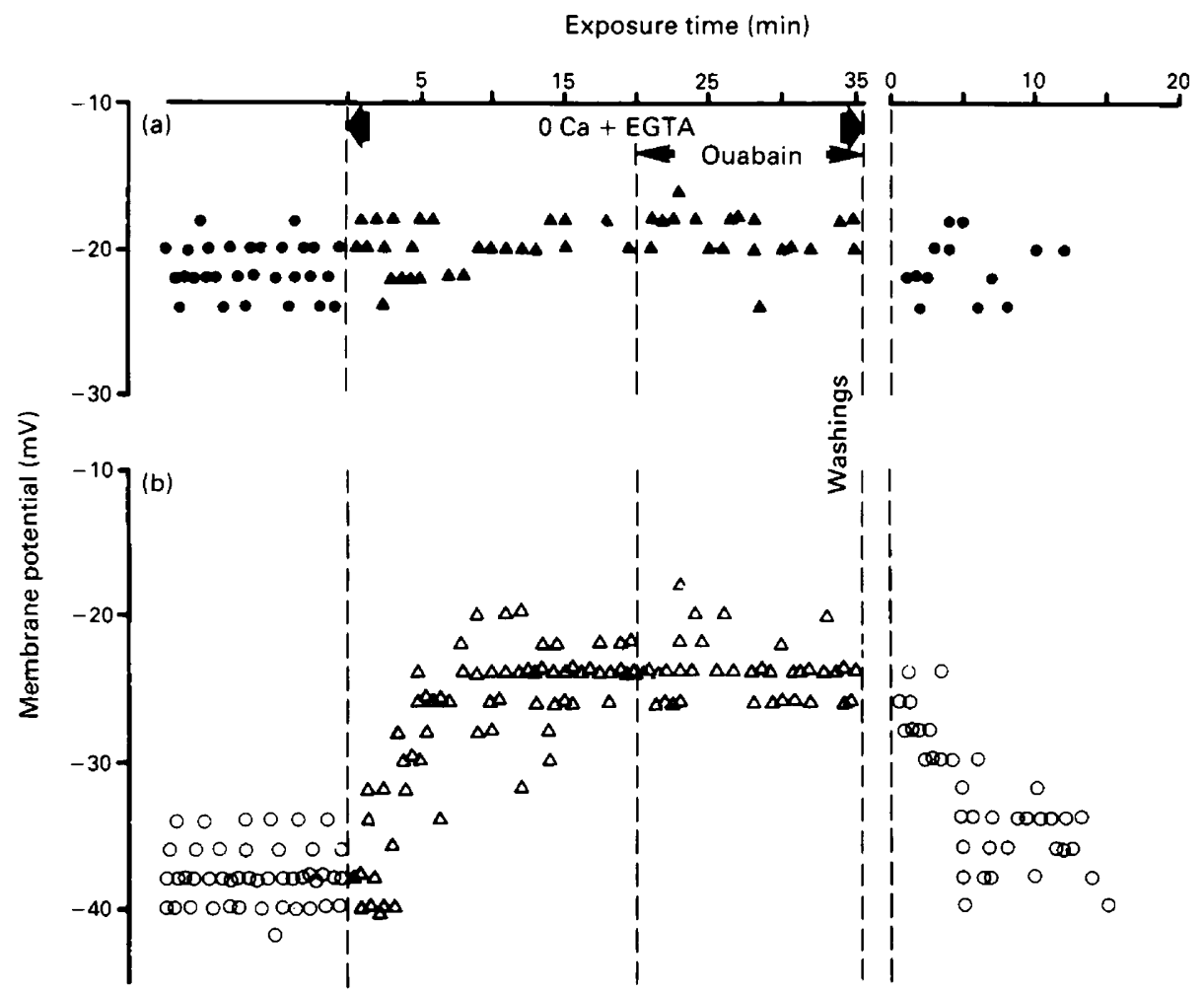

Fig. 6. Early effects of $0 \mathrm{Ca}+$ EGTA (1 mM) medium on the membrane potential of (a) unstimulated and (b) FSH-stimulated Sertoli cells. The cells were isolated from 17-day-old rats by Procedure 2 and cultured for 3-7 days before treatment. After the measurements of potential in the control electrophysiological medium $(\boldsymbol{O}, 0), 0 \mathrm{Ca}+$ EGTA $(1 \mathrm{~mm})$ medium was added and membrane potentials were recorded at different times of exposure $(\boldsymbol{\Delta}, \Delta)$. After $20 \mathrm{~min}$, ouabain $\left(10^{-4} \mathrm{M}\right)$ was added and membrane potentials were recorded. After $15 \mathrm{~min}, 0 \mathrm{Ca}+$ EGTA medium containing ouabain was washed out and replaced by the control medium. Each point represents the membrane potential of one impaled cell. Data were obtained from 3 cultures. 
monolayer from the bottom of the Petri dish and prevented the use of microelectrode techniques. Therefore, the Sertoli cells were first stimulated by a 24-h exposure to FSH $(2.0 \mu \mathrm{g} / \mathrm{ml})$, then the culture medium was discarded and replaced by $0.5 \mathrm{ml} 0 \mathrm{Ca}-0 \mathrm{Mg}$ Earle's solution containing trypsin $(0.05 \%)$. After a $5-10-\mathrm{min}$ period of incubation at $34^{\circ} \mathrm{C}$, the monolayers were transferred to a conical tube containing RPMI medium with fetal calf serum $(10 \%)$ and then centrifuged $(70 \mathrm{~g}$, $6 \mathrm{~min}, 20^{\circ} \mathrm{C}$ ). The pellet was then suspended in Medium RPMI and dispersed by being passed through a syringe needle, as during preparation of the Sertoli cells. The Sertoli cells were then plated by the usual procedure. After a second 3-day culture, the measurement of membrane potential was performed. The data are summarized in Table 2. The FSH-induced hyperpolarization was suppressed and a second exposure to $\mathrm{FSH}$-induced a new hyperpolarization of the cell to values near those of stimulated cells $(P<0 \cdot 01)$.

Table 2. Effects of a second FSH stimulation on membrane potentials of immature rat Sertoli cells in monolayer culture recorded after a trypsin treatment followed by a mechanical dispersion

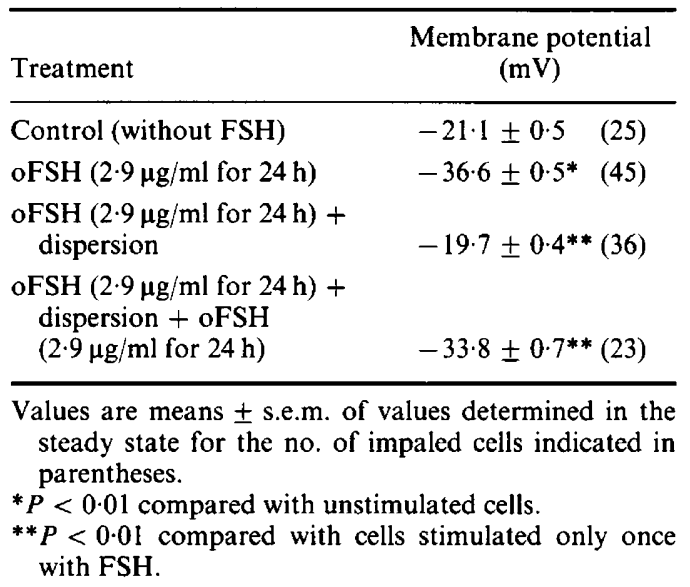

\section{Discussion}

Conventional cultures of Sertoli cells on plastic Petri dishes have been extensively used for studying the structure, function and FSH regulation of cellular metabolism and secretion (Dorrington et al., 1975; Steinberger et al., 1975; Welsh \& Wiebe, 1975; Verhoeven et al., 1979; Rich et al., 1983). We decided to use two of them to explore the electrophysiology of Sertoli cells and their FSH stimulation (Joffre \& Roche, 1988).

The first experiments were performed on Sertoli cells which were isolated by Procedure 1, but most were carried out on cells isolated by Procedure 2. Procedure 2 gave a more homogeneous monolayer of cells which grew without fetal calf serum, omission of which did not noticeably modify the cell response to FSH (Verhoeven et al., 1980) and enhanced the electrical response to this hormone (Joffre \& Roche, 1988).

In spite of the epithelial structure of Sertoli cells in monolayer culture which is different from the cellular organization in testis, our electrophysiological study has yielded results which largely support the radioisotopic and chemical analysis of ionic components of fluid production (for review: Waites \& Gladwell, 1982) and the electrophysiological study on the whole seminiferous 
tubule (Cuthbert \& Wong, 1975). Our study gave maximal values of membrane potential equal to those determined in situ through the tubular wall by Cuthbert \& Wong (1975).

It showed that ovine FSH caused a dose-dependent hyperpolarization of cell. As the FSH concentration rose from 0 to $2.9 \mu \mathrm{g} / \mathrm{ml}$, the membrane potential progressively increased with the maximal value equal to $-37 \cdot 0 \pm 0 \cdot 2 \mathrm{mV} ; n=310$ ) when the cells were prepared by Procedure 2 . It is significantly lower when the cells were prepared by the Procedure $1(-30.5 \pm 0.3 \mathrm{mV} ; n=277$; $P<0 \cdot 01$ ). This response appears not to be modified by the culture period (Joffre \& Roche, 1988).

Many electrophysiological studies on exocrine glands have shown that treatments which affect the functional state of the junctional complex linking neighbouring cells modify the recordings obtained by the intracellular microelectrode method (Iwatsuki \& Petersen, 1978a, b; Loewenstein, 1981). Therefore, with the purpose of examining whether the junctional complex between Sertoli cells may affect the FSH-induced hyperpolarization and to obtain complementary results on the FSH stimulation, Sertoli cells were exposed to treatments known to suppress or to decrease the intercellular electrical coupling in different structures, including salivary gland, myocardium or neurones (Loewenstein et al., 1967; Délèze, 1970; De Mello, 1975; Rose \& Loewenstein, 1975, 1976; Johnston et al., 1980; Délèze \& Hervé, 1983). All these treatments, which involve an increase in intracellular calcium (A 23187, heptanol, CCmP) or a decrease of extracellular calcium $(0 \mathrm{Ca}+$ EGTA) induce a fast and significant depolarization of FSH-stimulated cells to an unstimulated level. All the procedures, with exception of an exposure to $\mathrm{CCmP}$, slightly decrease the membrane potential of unstimulated cells. The effects are either partly (A 23187 and CCmP) or totally (heptanol and $0 \mathrm{Ca}+$ EGTA) reversed by a recovery period in a drug-free medium.

All these results suggest that calcium and/or the degree of coupling between Sertoli cells modify the FSH-induced hyperpolarization. The recorded depolarization may be related to the calcium sensitivity of the $\mathrm{Na} / \mathrm{K}$ pump (which is inhibited by uncoupling treatments (Fig. 6)) and of the K channels responsible for this hyperpolarization (Joffre \& Roche, 1988).

The FSH-induced hyperpolarization did not disappear after a recovery period in a hormonefree medium (Fig. 1), even when the cells were bathed in a $\mathrm{pH} 3$ medium to break down the bound FSH. It was only cancelled after an exposure to trypsin followed by a new mechanical dispersion (Table 2). Such a trypsin treatment reproduced the experimental procedure used for isolating the Sertoli cells from the testes. This may explain the same values of membrane potential measured on unstimulated cells isolated before and after the appearance of the blood-testis barrier (Vitale et al., 1973) and the same response to the FSH stimulation.

Direct communication pathways are present in the seminiferous tubules between neighbouring cells (Johnson, 1970). They are mediated by a junctional complex including tight and gap junctions which were observed in situ in the seminiferous tubule (Dym \& Fawcett, 1970; Vitale et al., 1973; Gilula et al., 1976) and in vitro, either in culture of whole seminiferous tubule (Meyer et al., 1977) or in monolayer cultures of Sertoli cells (Solari \& Fritz, 1978; Hadley et al., 1985).

An effect of FSH on the junctional complex was previously determined by an ultrastructural study on a monolayer of Sertoli cells cultured in the same conditions as in our own experiment (Solari \& Fritz, 1978). It showed that the Sertoli cells isolated from testes of 10-day-old rats and cultured in medium without FSH did not develop complete junctional complexes. These appeared only when the cells were stimulated by FSH and did not disappear after a recovery period in a hormone-free medium.

Direct evaluations of the electrical coupling between Sertoli cells in culture were made by means of two microelectrodes (Eusebi et al., 1985; unpublished data), and showed that unstimulated cells were effectively coupled. This coupling is decreased by A 23187 (Eusebi et al., 1985). The effects of uncoupling treatments on the membrane potential of cultured Sertoli cells therefore suggest that Sertoli cells are cells in which an electrical uncoupling is associated to a cellular depolarization, as in many cells (Loewenstein, 1981). The results are also consistent with the suggestion that Sertoli cells which should be weakly coupled in an unstimulated state, should be more electrically coupled after an FSH stimulation. Such an increase may be related to an increase in the conductance and/or 
to an increase in the number of gap junctions between neighbouring cells (Loewenstein, 1981). The effects of dibutyryl cAMP (Joffre \& Roche, 1988) suggest that this process is a cAMP-dependent mechanism as in many structures (Loewenstein, 1981; Hertzberg et al., 1981; Spray \& Bennett, 1985).

In the present study, the Sertoli cells grew in a conventional culture system, on a plastic Petri dish. They present little resemblance to the highly polarized cells in vivo. They have little cytoplasm and cell-cell junctions are occasionally located at the apex (Solari \& Fritz, 1978; Hadley et al., 1985). In these models high doses of FSH were generally used to stimulate the cells (Steinberger et al., 1978; Verhoeven et al., 1979). Similar high levels of FSH were used here to induce a membrane potential equal to those measured in vivo.

Attempts have been made to improve the morphology of Sertoli cells and prolong their secretory activity in culture. These include the use of serum-free and hormone-supplemented media, various reconstituted basal membranes and cell culture chambers with two compartments (Rich et al., 1983; Hadley et al., 1985, 1987; Djakiew et al., 1986; Janecki \& Steinberger, 1987). In these systems, Sertoli cells form a polarized monolayer with characteristic basally located tight junctions and they maintain germ cells in the basal part of the monolayer. Their secretory process is enhanced and they are more sensitive to FSH. Attempts are now being made to carry out these electrophysiological studies of FSH on such a model and to determine the effects of insulin and transferin on the FSH-induced hyperpolarization.

We thank Professor J. Délèze for helpful comments on this work; Miss Jeannette Gaudet, BA, English Department, University of Poitiers, for correcting the manuscript; P. Régondaud for technical assistance; J. Beaulieu for valuable secretarial help; and NIADDK for supplying the gonadotrophin.

\section{References}

Bernardini, G., Peracchia, C. \& Peracchia, L. (1984) Reversible effects of heptanol on gap junction structure and cell-to-cell electrical coupling. Eur. J. Cell Biol. 34, 307-312.

Bernier, M. \& Saez, J.M. (1985) Evidence de deux mécanismes impliqués dans le phénomène de la régulation négative des récepteurs à l'hCG-LH. Développements récents de l'endocrinologie du testicule. Colloque INSERM 1984 123, 239-244.

Cuthbert, A.W. \& Wong, P.Y.D. (1975) Intracellular potentials in cells of the seminiferous tubules of rats. J. Physiol., Lond. 248, 173-191.

Délèze, J. (1970) The recovery of resting potential and input resistance in sheep heart injured by knife or laser. J. Physiol., Lond. 208, 547-562.

Délèze, J. \& Hervé, J.C. (1983) Effect of several uncouplers of cell-to-cell communication on gap junction morphology in mammalian heart. J. Membrane Biol. 74, 203-215.

De Mello, W.C. (1975) Effect of intracellular injection of calcium and strontium on cell communication in heart. J. Physiol., Lond. 250, 231-245.

Djakiew, D., Hadley, M.A., Byers, S.W. \& Dym, M. (1986) Transferrin-mediated transcellular transport of ${ }^{59} \mathrm{Fe}$ across confluent epithelial sheets of Sertoli cells grown in bicameral cell culture chambers. $J$. Androl. 7, 356-366.

Dorrington, J.H., Roller, N.F. \& Fritz, I.B. (1975) Effects of follicle-stimulating hormone in culture of Sertoli cell preparations. Molec. cell. Endocrinol. 3, $57-70$.

Dym, M. \& Fawcett, D.W. (1970) The blood-testis barrier in the rat and the physiological compartmen- tation of the seminiferous epithelium. Biol. Reprod. 3, 308-326.

Eusebi, F., Grassi, F., Framico, G., Dolci, S., Conti, M. \& Stefanini, M. (1985) Cell-to-cell communication in cultured Sertoli cells. Pflügers Arch. 404, 382-384.

Gilula, N.B., Fawcett, D.W. \& Aoki, A. (1976) The Sertoli cell occluding junctions and gap junctions in mature and developing mammalian testis. Devl Biol. 50, 142-168.

Ginsborg, B.L. \& House, C.R. (1980) Stimulus-response coupling in gland cells. Ann. Rev. Biophys, Bioengen. 9, 55-80.

Hadley, M.A., Byers, S.W., Suarez-Quian, C.A., Kleinman, H.K. \& Dym, M. (1985) Extracellular matrix regulates Sertoli cell differentiation, testicular cord formation, and germ cell development in vitro. J. Cell Biol. 101, 1511-1522.

Hadley, M.A., Djakiew, D., Byers, S.W., Dym, M. (1987) Polarized secretion of androgen-binding protein and transferrin in Sertoli cells grown in a bicameral culture system. Endocrinology 120, 1097-1103.

Hagenas, L., Ploen, L. \& Ekwall, H. (1978) Blood-testis barrier: evidence for intact inter-Sertoli cell junctions after hypophysectomy in the adult rat. $J$. Endocr. 76, 87-91.

Hertzberg, E.L., Lawrence, T.S. \& Gilula, N.B. (1981) Gap junctional communication. Ann. Rev. Physiol. 43, 479-491.

Iwatsuki, N. \& Petersen, O.H. (1978a) Pancreatic acinar cells: acetylcholine-evoked electrical uncoupling and its ionic dependency. J. Physiol., Lond. 274, 81-96.

Iwatsuki, N. \& Petersen, O.H. (1978b) Membrane potential, resistance and intercellular communication in 
the lacrimal gland: effects of acetylcholine and adrenaline. J. Physiol., Lond. 275, 507-520.

Janecki, A. \& Steinberger, A. (1987) Bipolar secretion of androgen binding protein and transferrin in Sertoli cells cultured in a two compartment culture chamber. Endocrinology 120, 291-298.

Joffre, M. \& Roche, A. (1988) Follicle stimulating hormone induces the hyperpolarization in immature rat Sertoli cells in monolayer culture. J. Physiol., Lond. 400, 481-499.

Joffre, M., Mollard, P., Régondaud, P., Alix, J., Poindessault, J.P., Malassiné, A. \& Gargouñ, Y.M. (1984) Electrophysiological study of single Leydig cells freshly isolated from rat testis. I. Technical approach and recordings of the membrane potential in standard solution. Pflügers Arch. 401, 239-245.

Johnson, M.H. (1970) Changes in the blood-testis barrier of the guinea-pig in relation to histological damage following iso-immunization with testis. $J$. Reprod. Fert. 22, 119-127.

Johnston, M.F., Simon, S.A. \& Ramon, F. (1980) Interaction of anaesthetics with electrical synapses. Nature, Lond. 282, 498-500.

Loewenstein, W.R. (1981) Junctional intercellular communication: the cell-to-cell membrane channel. Physiol. Rev. 61, 829-913.

Loewenstein, W.R., Nakas, M. \& Socolar, S.J. (1967) Junctional membrane uncoupling. Permeability transformations at a cell membrane junction. J. gen. Physiol. 50, 1865-1891.

Means, A.R., Dedman, J.R., Tash, J.S., Tindall, D.J., Van Sickle, M. \& Welsh, M.J. (1980) Regulation of the testis Sertoli cell by follicle stimulating hormone. Ann. Rev. Physiol. 42, 59-70.

Meyer, R., Posalaky, Z. \& McGinley, D. (1977) Intercellular junction development in maturing rat seminiferous tubules. J. Ultrastr. Res. 61, 271-283.

Petersen, O.H. (1980) The Electrophysiology of Gland Cells. Academic Press, London.

Plant, T.D., Standen, N.B. \& Ward, T.A. (1983) The effects of injection of calcium ions and calcium chelators on calcium channel inactivation in Helix neurones. J. Physiol., Lond. 334, 189-212.

Poisner, A.M. \& Trifaro, J.M. (1985) The Electrophysiology of the Secretory Cell. Elsevier, Amsterdam.

Politoff, A.L., Socolar, S.J. \& Loewenstein, W.R. (1969) Permeability of a cell membrane junction. Dependence on energy metabolism. J. gen. Physiol. 53, 498-515.

Rich, K.A., Bardin, W.C., Gunsalus, G.L. \& Mather, J.P. (1983) Age-dependent pattern of androgen-binding protein secretion from rat Sertoli cells in primary culture. Endocrinology 113, 2284-2293.

Roche, A. (1986) Etude électrophysiologique de la fonction exocrine de la cellule de Sertoli en culture, isolée du testicule de rat immature. Effets de l'hormone FSH. Thèse de Doctorat d'Etablissement, Université de Poitiers (no. 31).

Roche, A. \& Joffre, M. (1985) Effet irréversible de FSH sur le potentiel de membrane de la cellule de Sertoli en culture. J. Physiol., Paris 80, 58A, Abstr.

Roche, A. \& Joffre, M. (1986) Effets de traitements découplants sur le potentiel de membrane de la cellule de Sertoli stimulée ou non par FSH. J. Physiol., Paris 81, 33A, Abstr.

Rosario, L.M., Atwater, I. \& Rojas, E. (1985) Membrane potential measurements in islets of Langerhans from ob/ob obese mice suggest an alteration in $\left[\mathrm{Ca}^{2+}\right]_{i}-$ activated $\mathrm{K}^{+}$permeability. $Q$. Jl exp. Physiol. 70, 137-150.

Rose, B. \& Loewenstein, W.R. (1979) Permeability of cell junction depends on local cytoplasmic calcium activity. Nature, Lond. 254, 250-252.

Rose, B. \& Loewenstein, W.R. (1976) Permeability of a cell junction and the local cytoplasmic free ionized calcium concentration. J. Membr. Biol. 28, 87-119.

Rose, B. \& Rick, R. (1978) Intracellular pH, intracellular free $\mathrm{Ca}$, and junctional cell-cell coupling. J. Membr. Biol. 44, 377-415.

Saez, J.M., Forest, M.G., Dazord, A. \& Bertrand, J. (1985) Développements récents de l'endocrinologie du testicule. Colloque INSERM 123.

Setchell, B.P. (1970) The secretion of fluid of rats, rams and goats with some observation on the effect of age, cryptorchidism and hypophysectomy. J. Reprod. Fert. 23, 79-85.

Solari, A. \& Fritz, I.B. (1978) The ultrastructure of immature Sertoli cells. Maturation-like changes during culture and the maintenance of mitotic potentiality. Biol. Reprod. 18, 329-345.

Spray, D.C. \& Bennett, M.V.L. (1985) Physiology and pharmacology of gap junctions. Ann. Rev. Physiol. 47, 281-303.

Steinberger, A., Heindel, J.J., Lindsey, J.N., Elkington, J.S.H., Sanborn, B.M. \& Steinberger, E. (1975) Isolation and culture of FSH responsive Sertoli cells. Endocr. Res. Commun. 2, 261-272.

Steinberger, A., Hintz, M. \& Heindel, J.J. (1978) Changes in cyclic AMP responses to FSH in isolated rat Sertoli cells during sexual maturation. Biol. Reprod. 19, 566-572.

Vassort, G., Whittembury, J. \& Mullins, L.J. (1986) Increases in internal $\mathrm{Ca}^{2+}$ and decreases in internal $\mathrm{H}^{+}$ are induced by general anesthetics in squid axons. Biophys. J. 50, $11-19$.

Verhoeven, G., Dierickx, P. \& De Moor, P. (1979) Stimulation effect of neurotransmitters on the aromatization of testosterone by Sertoli cell-enriched cultures. Molec. cell. Endocrinol. 13, 24l-245.

Verhoeven, G., Cailleau, J. \& de Moor, P. (1980) Desensitization of cultured rat Sertoli cells by follicle stimulating hormone and by L-isoproterenol. Molec. cell. Endocrinol. 20, 113-126.

Vitale, R., Fawcett, D.W. \& Dym, M. (1973) The normal development of the blood testis barrier and the effects of clomiphene and estrogen treatment. Anat. Rec. 176, 333-344.

Waites, G.M.H. \& Gladwell, R.T. (1982) Physiological significance of fluid secretion in the testis and bloodtestis barrier. Physiol. Rev. 62, 624-671.

Welsh, M.J. \& Wiebe, J.P. (1975) Rat Sertoli cells: a rapid method for obtaining viable cells. Endocrinology 96, 618-624.

Received 11 December 1987 